\title{
Reinvestigando a Natureza Jurídica da Propriedade
}

\section{José Vander Tomaz Chaves}

Mestre em Direito pela Universidade Federal do Ceará. Especialista em Direito Privado pela Universidade de Fortaleza. Professor da Faculdade 7 de Setembro. Diretor do Núcleo Judiciário da Justiça Federal no Ceará. vanderchaves@hotmail.com

Sumário: 1. Propriedade e função social. 2. Natureza jurídica da função social da propriedade. 3. Reflexos do princípio da função social para a reinvestigação da natureza jurídica da propriedade. Considerações finais. Referências.

Resumo: A concepção do Estado Intervencionista, resultante de um processo dialético histórico verificado entre o Estado Liberal e o Socialista, permitiu a consagração de uma função social a ser desempenhada pelos titulares da propriedade. Com isso, passou a ser exigida dos proprietários uma conduta voltada à satisfação de seus interesses individuais, desde que compatibilizada ao interesse coletivo. Tal circunstância gerou uma ruptura no modo com o qual a propriedade se via consubstanciada na seara jurídica, uma vez que não mais consistia numa mera facultas agendi concedida ao proprietário, mas também numa fonte de deveres. Para alguns, a propriedade ter-se-ia convertido em função social. Contudo, é a noção de direito subjetivo que houve de ser revisitada ante o intervencionismo do Estado, passando a propriedade a ser compreendida como direito orientado por uma função social.

Pallavras-chave: Função social da propriedade. Liberalismo. Socialismo. Direito subjetivo.

\section{PROPRIEDADE E FUNÇÃO SOCIAL}

O regime capitalista inaugurado pelas revoluções liberais proclamava ampla liberdade no exercício do direito de propriedade, ocasionando, de certo modo, um retorno à sua concepção romana. O Estado deveria, segundo o pensamento liberal, limitar-se a respeitar e garantir os direitos dos indivíduos. Essa ampla liberdade acabou por gerar um enriquecimento desenfreado para alguns e um consequente empobrecimento para outros, uma vez que, naquele contexto, não havia como se conceberem ganhos sem que houvesse perdas correspondentes. Abriu-se ensejo, pois, à concentração de riqueza nas mãos de poucos, ladeados pela massa de desafortunados, empregados ou não, que apenas possuíam sua força de trabalho. Essa é a resenha daquilo que motivaria o declínio do capitalismo 
puro (liberal): crescente alta inflacionária e estagnação econômica gerada pelo excesso de produção e pela parca demanda. A expressão maior dessa realidade veio a ocorrer em 1929, com a quebra da Bolsa de Nova Iorque.

Esse foi o contexto em que sementes de novas ideias passaram a ser lançadas, despertando a efetivação do ideário socialista, numa fase de transição narrada por Dalmo de Abreu Dallari:

O industrialismo do século XIX, ao mesmo tempo em que procurara levar às últimas conseqüências os princípios individualistas do liberalismo, promovera a concentração dos indivíduos que nada mais possuíam do que a força de trabalho. Com isto, iria deixar muito evidente a existência de desníveis sociais brutalmente injustos e favorecer a organização do proletariado como força política. Além disso, patenteou aos intelectuais e aos líderes não condicionados por interesses econômicos a necessidade imperiosa de se implantar uma nova ordem social, em que os homens recebessem proteção e tivessem meios de acesso aos bens sociais. E a Revolução Russa, de outubro de 1917, abrindo o caminho para o Estado Socialista, iria despertar a consciência do mundo para a necessidade de assegurar aos trabalhadores um nível de vida compatível com a dignidade humana. Surge, então, a consciência de que os indivíduos que não têm direitos a conservar são os que mais precisam do Estado (1995, p. 177).

Era o que Karl Marx havia profetizado ainda no século XIX. Para o jurista e economista tedesco, o modo de produção capitalista continha em si a semente de sua destruição. O intuito da acumulação ilimitada de capital conduziria à cessação de sua fonte, o mercado, o qual quedaria paralisado pelo empobrecimento dos consumidores. Para ele, o proletariado não poderia aguardar a autodestruição do sistema então vigente (SANTOS, 2004, p. 38).

Marx concebeu também a implantação do comunismo, processo que se iniciaria pela fase do socialismo, no momento em que o proletariado tomasse ciência da exploração a que estava submetido ${ }^{1}$, consubstanciada na apropriação da mais-valia pelos detentores do capital. Estabelecer-se-ia, a partir daí, a ditadura do proletariado, na qual seriam realizadas expropriações em face dos particulares ${ }^{2}$. Esse período ditatorial seria, segundo Marx, necessário para que os homens se desapegassem da ideia de apropriação individual.

\footnotetext{
1 Para Marx, a mudança que o proletariado proporcionaria em desfavor dos interesses dos detentores do capital seria uma renovação histórica do que um dia estes fizeram em desfavor da nobreza e da realeza, quando se aperceberam do poder que possuíam. O mesmo ocorreria agora com os proletários: "Com o desenvolvimento da indústria, não somente aumenta o número de proletários, mas estes são concentrados em massas cada vez mais consideráveis; sua força cresce e eles adquirem maior consciência dela" (MARX, 1988, p. 84).

2 "A primeira fase da revolução operária é o advento do proletariado como classe dominante [...]. Isto só poderá ser conquistado, a princípio, por uma violação despótica do direito de propriedade de das relações de produção burguesas" (MARX, 1988, p. 95).
} 
Isso ocorrido, poder-se-ia estabelecer o comunismo, no qual se apresentaria desnecessário o controle estatal da não acumulação de bens, pois o homem já haveria retornado ao status anterior da propriedade comunal. Assim, vê-se que o socialismo seria uma fase preparatória do comunismo. Este representaria, por sua vez, "a eliminação positiva da propriedade privada como autoalienação humana pelo e para o homem [...], o retorno do homem a si mesmo como ser social" (MARX, 2001, p. 138) ${ }^{3}$.

A fase do socialismo viu-se corporificada a partir da Revolução Russa de 1917, através da qual aquele regime foi implantado na Rússia, apondo termo ao reinado dos czares. Abriram-se, através dela, ensanchas para a adoção do socialismo em diversos outros países, mormente na Ásia e no leste da Europa. A passagem ao comunismo, contudo, não se chegou a verificar na empiria.

Com efeito, o que se verificou historicamente foi a circunstância de que a supressão do socialismo nos países que o adotaram conduziu, em verdade, ao modo de produção capitalista. Foi o que ocorreu nos países da Europa oriental, v.g. Isso se explica pela inclinação natural do homem à democracia e à liberdade, o que não se observava no regime preconizado por Marx. Não mais conduzido e limitado pelo socialismo, o homem buscou naturalmente a satisfação de seus interesses particulares, o que refletiu no retorno à apropriação individual. Ora, se um dia o homem associou sua liberdade à satisfação de suas necessidades para inaugurar a apropriação particular, vê-se ser essa sua tendência essencial e, apenas sob rígido controle - limitação da liberdade - tal tendência não se manifestará.

Constata-se dessa análise que ambos os sistemas - capitalista e socialista apresentaram vantagens e falhas, mas se pode perceber que são tais notas fincadas na ideia de exacerbação: o capitalismo conferiu extrema liberdade ao homem; o socialismo, liberdade extremamente restrita.

Solapado por duas Grandes Guerras e por intensa crise política e social, o capitalismo ocidental viu ameaçada a sua integridade, a qual apenas poderia ser obstada pela concessão aos apelos socialistas, num verdadeiro esforço dialético. Evidenciava-se que a complementação entre esses sistemas poderia conduzir a um Estado aprimorado, em que haveria uma maior adequação entre os interesses individuais e coletivos, associada a uma maior estabilidade econômica.

\footnotetext{
3 A ideia da autoalienação humana é explicada por Marx: "A propriedade privada tornou-nos tão estúpidos e parciais que um objeto só é nosso quando o temos, quando existe para nós como capital ou quando por nós é diretamente possuído, comido, bebido, transportado no corpo, habitado, etc., ou melhor, quando é utilizado [...]. Todos os sentidos físicos e intelectuais foram substituídos pela simples alienação de todos os sentidos, pelo sentido do 'ter' [...]. A supressão da propriedade privada constitui, desse modo, a emancipação total de todos os sentidos e qualidades humanas" (MARX, 2001, p. 142).
} 
É o que parece haver percebido John Maynard Keynes, pai do intervencionismo, teoria que pode ser vislumbrada como síntese da dialética entre capitalismo e socialismo. A doutrina intervencionista reuniu elementos de ambas as já mencionadas, embora que com nenhuma delas se confundisse. Não seria liberal, por negar o Estado eminentemente absenteísta, nem socialista, uma vez que o Estado intervencionista não é produtor, mas conciliador dos interesses de produtores e consumidores. Não se trata de Estado da burguesia ou do proletariado; de Estado de uma classe, mas de Estado de todas as classes.

O pensamento esposado por Galbraith ilustra com maestria e simplicidade as alterações impostas pela adoção da doutrina intervencionista:

The Keynesian system, though it implied a decidedly non-revolutionary change in the relation of the government to the economy, implied, nonetheless, an important one. For a doctrine that excluded government it substituted one that made government indispensable. Keynes [... ] went on to make government the indispensable partner of business (1952, p. 84).

O intervencionismo importou uma reformulação da secessão entre sociedade e Estado, preconizada pelo liberalismo ${ }^{4}$. O Estado abandonou o papel de mero árbitro e produtor do direito e passou a agir ativamente perante a economia. A "mão invisível" a que se referira Adam Smith fez-se palpável.

A doutrina do intervencionismo começou a ganhar força nos anos que precederam a II Guerra Mundial (1939-1945), havendo obtido, depois dela, maior efetivação, por conta da consciência que surgia nos países capitalistas acerca da fragilidade de seu regime e da consequente necessidade de sua retificação. Já se manifestavam traços daquela doutrina na política do N ew D eal, praticada pelo presidente americano Franklin Delano Roosevelt durante a Grande Depressão na década de 30. Finda a guerra, o intervencionismo manifestou-se ainda mais veemente, ante os clamores surgidos para a ação do Estado para o reerguimento das cidades e das atividades produtivas.

Não almejava Keynes a condução ao socialismo por parte dos países que adotavam o sistema capitalista, mas uma reformulação da visão clássica deste, numa superação do seu modelo liberal. Daí as esclarecedoras observações de Lawrence Klein, para quem:

Las reformas keynesianas no atacan ni inciden sobre los derechos privados delas personas a sus propios
bienes de producción. La investigación keynesiana mira al E stado como un poder equilibrador que
únicamente sirve para complementar la conducta y actuación de los capitalistas individuales, mientras
que la doctrina socialista considera al Estado como empresario único que reemplaza por entero toda
actividad privada capitalista. La política keynesiana, en realidad, es conservadora porque apunta a
conservar el capitalismo de empresa libre. E I socialismo no es conservador, es radical, y apunta a
cambiar el sistema capitalista en otro sistema totalmente distinto (1952, p. 206).

4 Para José de Albuquerque Rocha, uma das características do Estado liberal é a "separação entre sociedade e Estado ou, por outras palavras, entre economia e política” (ROCHA, 1995, p. 126). 
Nesse contexto, viu-se alterado o próprio papel do direito na vida econômica. No Estado Liberal, o direito visava precipuamente à garantia das liberdades individuais, enquanto, no nascente Estado Social, assumia um viés promocional. As Constituições dos Estados passavam a tratar da ordem econômica, o que "é expressiva de marcante transformação que afeta o Direito, operada no momento em que deixa de exclusivamente prestar-se à harmonização de conflitos e à legitimação do poder, passando a funcionar como instrumento de implementação de políticas públicas" (GRAU, 1990, p. 13). Até mesmo o Poder Judiciário, antes mero garantidor das instituições liberais, viu-se "realizador de políticas públicas visando à modificação da realidade social e econômica" (ROCHA, 1995, p. 133).

A concepção do Estado intervencionista efetivou com maior visibilidade o afã coletivo já principiado pelo welfare state (estado do bem-estar social), cujas raízes já se viam fincadas ao final da I Guerra Mundial, abrindo-se espaço para que as incipientes modificações impostas ao direito de propriedade encontrassem um vasto campo para a sua ampliação. Evidência de tal conjuntura é o fato de a primeira Constituição brasileira do segundo pós-guerra, a de 1946, haver iniciado no direito pátrio o explícito reconhecimento de que o exercício do direito de propriedade é condicionado ao bemestar social. Essa renovação da regulação jurídica da propriedade já se apresenta, em si, como um meio de intervenção, como pontifica Eros Roberto Grau, para quem "a mera produção do Direito, a simples definição das esferas do público e do privado [...] desde logo consubstanciam expressões de atuação interventiva estatal" (1990, p. 17).

Nesse diapasão, o pensamento de Adolpho Pinto Filho, compartilhado com Beviláqua, em que se ressaltou o nítido caráter dialético do regime econômico que então se passava a divisar:

No novo regime, que conciliará as vantagens do socialismo e do individualismo, dar-se-á um novo equilíbrio social. Não desaparece nem o capitalismo, ainda necessário, nem o excitante regime da concorrência, mas muito serão diminuídos os desperdícios e injustiças do regime atual (apud BEVILÁQUA, 1976, p. 132).

Com efeito, é inegável que o regime intervencionista não surgiu para eliminar o capitalismo, mas para obstar seu declínio ${ }^{5}$, corrigindo-lhe as notas de extrema liberdade conferida ao indivíduo e ampliando a ação positiva do Estado perante a economia. Daí ser viável considerar que a superação imposta pelo intervencionismo conduziu a um

\footnotetext{
5 "A virada do século assiste ao declínio do capitalismo concorrencial liberal. A economia de guerra e o advento da revolução bolchevista desferem-lhe golpes mortais. Sombrio o futuro do capitalismo, impunha-se a sua renovação [...]. Evidente a inviabilidade do capitalismo liberal, o Estado [...] assume o papel de agente regulador da economia" (GRAU, 1990, p. 18 e 44).
} 
capitalismo renovado, que se pode qualificar de intervencionista, distinto do capitalismo puro (liberal) preconizado pelos revolucionários de 1789. Como afirma Eros Grau, o novo papel que passou a ser desempenhado pelo Estado "não conduz à substituição do sistema capitalista por outro". Para ele, "é justamente a fim de impedir tal substituição [... que o Estado é chamado a atuar sobre o domínio econômico. O sistema capitalista é assim preservado, renovado sob diverso regime" (1990, p. 61). "O Estado do bemestar ainda é uma máquina essencialmente capitalista” (GRAU, 1995, p. 63) . A função social da propriedade, por seu turno, transforma a propriedade capitalista, sem socializá-la (MIRANDA, 1989, p. 91).

A propriedade hodierna se apresenta, pois, como produto da dialética travada entre liberalismo e socialismo ${ }^{7}$, não sendo apressado concluir que a efetiva modificação do status jurídico da propriedade para os contornos que se lhe apresentam na atualidade apenas foi perpetrada quando se passou a verificar na concretude o regime preconizado pelo intervencionismo. Contudo, não se pode olvidar que a modificação da óptica do direito de propriedade não nasceu nesse momento específico ou em qualquer outro. Trata-se de construção paulatina, fruto dos esforços doutrinários, ideológicos, políticos e materiais de vários pensadores, grupos e movimentos e de seu aprimoramento recíproco.

Com efeito, o germe da função social da propriedade pode ser encontrado já em Aristóteles $^{8}$ e nos jusfilósofos do Medievo, entre os quais

6 "A Para Norbert Reich, a mensagem básica do welfare state seria a de "transformar o capitalismo sem aboli-lo. Cumpre a ela explorar a vantagem principal das economias de mercado [...] sem ser o objeto de suas 'falhas', tais como exteriorizações, estruturas de poder desigual e distribuição injusta da riqueza" (1990, p. 265).

7 Esse aspecto é ratificado por Telga de Araújo, para quem, "no presente momento histórico, a propriedade traça as fronteiras entre o individualismo econômico - traço marcante da sociedade capitalista - e o socialismo - representado pela coletivização dos meios de produção" (1977, p. 2). Sahid Maluf também ressalta o caráter dialético da propriedade hodierna, ao afirmar que "o Estado social-democrático [...] procura harmonizar as verdades parciais e inegáveis que existem tanto no individualismo como no socialismo [...]. O Estado neutro e indiferente foi substituído pelo Estado atuante, intervencionista, cujo objetivo era o de restabelecer a harmonia tradicional entre capital e trabalho [...]. O Estado intervém [...] no direito de propriedade, impondo as restrições ditadas pelo interesse da coletividade" (MALUF, 1999, p. 133 e 306).

${ }^{8}$ Destoando de Platão, que defendia a propriedade comum, Aristóteles preconizava uma propriedade particular que coadunasse, a um só tempo, o interesse do dono e o da coletividade: “Tendo cada cidadão a sua propriedade particular, põe-na em parte ao serviço dos amigos, e dela se serve em parte como de um bem comum [...]. É preferível, portanto, que os bens sejam pertencentes a particulares porém que se tornem propriedade comum pelo uso que se faz deles [...]. Os que possuem em comum têm com muito mais freqüência questões entre si que os proprietários de bens separados [... . Encontrar-se-iam aí] os benefícios dos dois sistemas, quer dizer, da propriedade possuída em comum e da posse individual, concomitantemente" (ARISTÓTELES, 2002, p. 44-45). 


\begin{abstract}
Santo Ambrósio, propugnando por uma sociedade mais justa com a propriedade comum, ou Santo Agostinho, condenando o abuso do homem em relação aos bens dados por Deus, e Santo Tomás de Aquino, que vê na propriedade um direito natural que deve ser exercido com vista ao bonum commune (ARAÚJO, 1977, p. 7).
\end{abstract}

Foi através daqueles padres-filósofos, inclusive, que passou a ser formado materialmente o posicionamento da Igreja acerca da matéria, corporificado em diversas encíclicas que representaram influência para a evolução da ideia de propriedade, entre as quais podem ser destacadas a Rerum Novarum ${ }^{9}$ (1891), Leão XIII; Q uadragesimo Anno $^{10}$ (1931), de Pio XI; e M ater et M agistra ${ }^{11}$ (1961), de João XXIII. Pode-se a elas avizinhar a encíclica Libertas Præstantissimum (1888), também elaborada por Leão XIII, na qual aquele pontífice questiona a liberdade preconizada pela doutrina liberal, uma vez que dissociada do bem comum ${ }^{12}$.

Foi na metade do século XIX, com o positivismo de Auguste Comte, que se viu inaugurada a terminologia função social da propriedade, nos termos que se transcrevem:

Les sentiments d'invidualisme comme les vues de détail ont dû prévaloir pendant la longue transition révolutionnaire qui nous sepaire du moyen age $M$ ais les uns conviennent encore moins que les autres à l'ordre final de la société moderne. D ans tout état normal de l'humanité, chaque citoyen quelconque constitue réellement um fonctionnaire public, dont les attributions plus ou moins définies déterminent à la fois les obligations et les prétentions. Ce principe universel doit certainement s'étendre jusqu'á la proprieté où le positivisme voit surtout une indispensable fonction sociale destiné à former et à administrer les capitaux par lesquels chaque génération prepare les travaux de la suivante. Sagement conçue, cette appréciation normale ennobilit sa possession, sans restreidre sa juste liberté, te même en la faisant mieux respecter (1851, p. 156, com grifos nossos).

Comte afirmava que a sua doutrina, em diversos aspectos, absorvia o que ele considerava a natureza social da propriedade e a necessidade de sua regulação, desenvolvendo tal ideário, por não o conceber incompatível com a propriedade privada:

É galement poussé par sa réalité caractéristique et sa tendence constante à consacrer la raison au service du sentiment, le positivisme est doublement entrané a systématizer le principle spontané du communisme sur la nature sociale de la proprieté et sur la necessité de la régler. Les vrais philosophes n'hesitent point à

\footnotetext{
9 "Não é das leis humanas, mas da natureza, que emana o direito da propriedade individual; a autoridade pública não o pode, pois, abolir, o que ela pode é regular-lhe e conciliá-lo com o bem comum”.

10 "Efetivamente, que deva o homem atender não só ao próprio interesse, mas também ao bem comum, deduz-se da própria índole, a um tempo individual e social, do domínio a que nos referimos".

11 "A propriedade privada, mesmo dos bens produtivos, é um direito natural que o Estado não pode suprimir. Consigo, intrinsecamente, comporta uma função social, mas é igualmente um direito que se exerce em proveito próprio e para o bem dos outros".

12 "Em uma sociedade humana, a verdadeira liberdade não consiste em fazer o capricho pessoal de cada um".
} 
sanctionner directement les réclamations instinctives des prolétaires envers la vicieuse définition adoptée par la plupart des juristes modernes, qui attribuent à la proprieéune individual ité absol ue, comme droit d'user et d'abuser. Cette théorie antisociale, historiquement due à une réaction exagérée contre des oppressiones exceptionelles, est autant dépourvue de justice que de réelité. Aucune proprieté ne pouvant être créé, nu même transmise, par son seul possesseur, sans une indispensable coopération publique, à la fois spéciale et gènèrale, son exercicene doit jamais être purement individuel (COM TE, 1851, p. 154-155).

Nessa esteira, mostrou-se essencial para a delimitação e difusão da ideia de função social da propriedade a doutrina do solidarismo social de Léon Duguit, cujos efeitos puderam ser sentidos logo no início do século XX, mormente entre a I e a II Guerra Mundial. Os traços basilares daquela doutrina são resenhados no excerto:

T odo individuo tiene en la sociedad una cierta función que cumplir, una cierta tarea que ejecutar. Y este $e s$ precisamenteel fundamento de la regla de derecho que se imponea todos, grandes y pequeños, gobernantes y gobernados [...]. T odo hombretiene una función social quellenar, y por consecuencia tieneel deber social de desempeñarla; tiene d deber de desenvolver, tan completamente como le sea posible, su individualidad física, intelectual y moral para cumplir esa función de la mejor manera posible y nadie puede entorpecer ese libre desenvolvimiento (DU GUIT, 1920, p. 36-37).

Essa teoria, segundo Arnaldo Vasconcelos,

investe contra os dogmas do civilismo clássico, a saber: a liberdade individual, o direito absoluto de propriedade, a autonomia contratual e o princípio da responsabilidade por culpa [...]. O princípio básico do solidarismo formula-se em atenção às possibilidades positivas e negativas do homem: nada fazer que prejudique a solidariedade social e tudo fazer para realizá-la e promovê-la. Assim agindo, o homem cumpre sua função social (1996, p. 112).

Inspirado pelo positivismo comteano, Duguit destacava, entre as várias funções que o homem deveria desempenhar em prol da sociedade, a propriedade, a qual consubstanciaria uma função social. Segundo ele, o dono teria, pela sua própria condição, uma função social a desempenhar. Enquanto o fizesse, seus atos estariam protegidos. Se não o fizesse ou o fizesse mal, deveria o Estado intervir para obrigá-lo a exercer sua função (DUGUIT, 1920, p. 14 et seq.).

Para aquele pensador, a propriedade somente se legitimaria através de sua utilidade social, a qual resultaria de verdadeira modificação em sua natureza. Segundo Duguit, a propriedade deixaria de ser encarada como direito subjetivo para passar a ser vislumbrada como função social (DUGUIT, 1923, p. 618).

Os próprios teóricos do capitalismo puro, através dos adeptos da corrente denominada marginalismo econômico, que pode ser considerada a última formulada sob a égide daquele regime, contribuíram no final do século XIX e início do século XX para a reformulação da visão que pairava sobre a propriedade, por considerar, entre outras coisas, que "as necessidades do homem satisfazem-se gradualmente e, na medida 
em que aumenta a quantidade de bens, reduz-se a satisfação por eles propiciada" (FALCÃO, 1981, p. 132), ou seja, os bens aumentam em relevância na medida em que diminuem em quantidade. Aqueles que mais têm veem nas coisas valor inferior àquele considerado por quem menos tem. Daí porque defendiam os marginalistas econômicos que o capital inútil gerado pelo excesso de acumulação deveria ser tributado para proporcionar a sua redistribuição. Defendiam eles, ainda, denotando de forma lúcida a insustentabilidade prática do capitalismo liberal, que

\footnotetext{
o grau de eficiência que os investimentos proporcionam à economia como um todo e, portanto, à sociedade, é de capital relevo na aferição do bem-estar social advindo do incremento de capital e dos seus efeitos, seja aumentando o produto nacional, seja corrigindo o fluxo de investimentos para regiões ou setores de maior interesse para a economia e para a sociedade (FALCÃO, 1981, p. 133).
}

Essa última corrente do capitalismo liberal exerceu influência não apenas para a concepção do regime intervencionista que assumia forma e logo se instalaria, mas, antes, no texto da Constituição mexicana de 1917 e na Constituição alemã de 1919, quando se inaugurava o Estado do Bem-Estar Social. O art. 27 da primeira estabelece, no tocante às "terras e águas compreendidas dentro dos limites do território nacional", a distinção entre a propriedade originária, que pertence à nação, e a propriedade derivada, que é gerada pela transmissão da primeira aos particulares, gerando a propriedade privada. Já se percebe ali a ideia de que o proprietário exerce uma espécie de múnus público, o que é reforçado por outros excertos daquele dispositivo, segundo o qual:

La N ación tendrá en todo tiempo el derecho de imponer a la propiedad privada las modalidades que dicte el interés público, así como el de regular, en beneficio social, el aprovechamiento de los elementos naturales susceptibles deapropiación, con objeto dehacer una distribución equitativa dela riqueza pública, cuidar desu conservación, lograr el desarrollo equilibrado de país y el de su conservación, lograr el desarrollo equilibrado del país y e mejoramiento de las condiciones de vida de la población rural y urbana.

Aboliu-se, destarte, em nível constitucional, o caráter absoluto da propriedade privada, submetendo-se o seu uso, incondicionalmente, ao interesse da coletividade. A Carta Mexicana de 05 de fevereiro de 1917, fruto da revolução instaurada naquele país em igual ano, apresenta-se como marco na história contemporânea, ante a notória ruptura que intentou perante o individualismo, consubstanciada, v.g., na remodelação jurídica da propriedade privada e na elevação dos direitos trabalhistas à condição de direitos fundamentais.

Já a Constituição de Weimar (1919), inspirada pela situação periclitante na qual se encontravam os trabalhadores na Alemanha do alvorecer do século passado e pelos elevados índices de desemprego então verificados naquele país, prescreve em seu art. 153: 
A Constituição garante a propriedade. O seu conteúdo e os seus limites resultam da lei. A expropriação tem de ser determinada pelo bem comum e dáse em virtude de disposições legais e mediante justa indenização, exceto nos casos declarados na lei. [...] A propriedade obriga. Seu uso deve ao mesmo tempo representar um serviço ao interesse social (com grifos nossos).

O texto exprime que a propriedade não consiste apenas em garantia do proprietário, mas gera também obrigações que por ele devem ser desempenhadas em favor da sociedade, noção que se vê reforçada pela primeira parte da terceira alínea do seu art. 155: "O proprietário do solo é obrigado perante a comunidade a cultivá-lo e explorá-lo".

A evolução da ideia de propriedade e a fundamentação teórica de sua função social, aqui sumariamente expostas, possuem não apenas o condão de propiciar um melhor entendimento acerca de seus delineamentos atuais, mas também de demonstrar o já mencionado dinamismo que paira sobre o seu regramento jurídico, o que corrobora a lição de Messineo, para quem "la propiedad es el instituto jurídico de mayor sensibilidad a las alteraciones económicas e sociales" (MESSINEO, 1954, p. 249). Explicita-se, assim, que a noção tida atualmente sobre a propriedade, a qual se fará adiante analisada, é uma das várias que se apresentaram e que preponderará até seja modificada pela força da história. Somente o tempo dirá como e quando.

\section{NATUREZAJURÍDICA DA FUNÇÃO SOCIAL DA PROPRIEDADE}

Toda a evolução antes apontada converge para a explicitação do caráter social que passou a ser gradativamente verificado na propriedade. Sua funcionalização, antes de vivenciada pelos ordenamentos dos diversos países, assumiu, em consequência do movimento dos tempos e dos esforços empreendidos pelos indicados pensadores e por tantos outros, a condição de um valor. Essa é a natureza primeira da função social da propriedade, a qual, durante muito tempo, não passou do plano axiológico - o que não obsta que tenha ela orientado a conduta de muitos.

Tal valor, como se analisou alhures, passou a ser incorporado aos ordenamentos, através de suas Constituições, numa tendência que timidamente se viu principiada. É inexata a noção de que a função social da propriedade existe somente no direito, pois este apenas a reconhece, juridicizando-a. Essa incorporação apenas insere no mundo jurídico aquele valor, o qual lhe é anterior. Do ensinamento de Cabral de Moncada extrai-se que

a Constituição não cria os valores: recebe-os e, do mesmo passo, positiva-os. [...] Ao positivá-los, dá-lhes seguramente um tratamento que é constitutivo do regime jurídico que para eles reconhece como sendo o mais adequado. [...] Os valores constitucionais [...] não são resultado de decisões normativas do poder constituinte ou constituído. Nenhum legislador os cria porque lhe são anteriores, apenas os reconhece e disciplina no seu articulado legal (2001, p. 393). 
Reconhecendo e disciplinando o valor correspondente à função social da propriedade, o legislador acaba por excluir da consagração da órbita jurídica valores com aquele inconciliáveis, como o são os decorrentes do liberalismo e do socialismo, em suas formas puras ou ideais.

Nos ordenamentos jurídicos em que a função social da propriedade se vê inserta, resulta ela caracterizada como princípio jurídico. Não se almeja, com isso, excluir o caráter axiológico daquela função, pois não há como negar que o direito assume as dimensões de fato, valor e norma, como explicitado magistralmente no tridimensionalismo realeano. Ocorre que a inserção daquele valor no direito, como princípio (norma), através do processo denominado dialética de implicação-polaridade, verificado na nomogênese, é o que lhe atribui juridicidade. Intenciona-se aqui ressaltar exatamente que aquele valor foi alçado ao nível jurídico, chegando a assumir o caráter de princípio. É o que se procurará demonstrar doravante.

Como ensina Miguel Reale, princípios jurídicos "são enunciações normativas de valor genérico, que condicionam e orientam a compreensão do ordenamento jurídico, quer para a sua aplicação e integração, quer para a criação de novas normas" (REALE, 2000, p. 306). Aquele autor chega a exemplificar como princípio a função social da propriedade, demonstrando, com tal indicação, coerência com o conceito por ele formulado, tendo em vista que:

a) diversas condutas podem ser enquadradas como adequadas ou infringentes à função social da propriedade, o que responde pelo caráter genérico desta; e

b) a efetivação da função social da propriedade manifesta-se precisamente nos sentidos preconizados pelo conceito de Reale - a aplicação ao caso concreto (isoladamente ou em comunhão com outros princípios ou regras), a colmatagem de eventuais lacunas no ordenamento jurídico e a elaboração de outras normas jurídicas (REALE, 2000, p. 307).

Igual conclusão também pode ser alcançada com fulcro no pensamento de Dworkin, o qual, ao proceder à distinção entre princípios e regras (1997, p. 72 et seq.), afirma que aqueles são caracterizados por:

a) não serem invalidados pela existência de outras normas com eles incompatíveis no mesmo ordenamento jurídico, ou seja, não se pode dizer que, ocorrido determinado fato concreto, a aplicação de uma outra norma em detrimento do princípio afasta a sua validade. Isso não ocorreria com as regras, as quais, segundo Dworkin - numa linguagem adequada à common law - , "son aplicadas a la manera de disyuntivas. Si los hechos que estipula una norma están dados, entonces o bién la norma éválida, en cuyo caso la respuesta debe ser aceptada, o bién no los es, y entonces no aporta nada a la decisión" (DWORKIN, 1997, p. 75); e 
b) possuírem uma dimensão de peso - dimension of weight - ou importância, a qual determinará se sua aplicação será prevalente ou mitigada em caso de haver conflito com outro princípio, de sorte que dois princípios podem ser considerados válidos, não obstante conflitantes: "Ios principios tienen una dimensión que falta a las normas: la dimensión del peso o importancia. Cuando los principios se interferen, quién debe resolver el conflicto tiene que tener en cuenta el peso relativo de cada uno" (DWORKIN, 1997, p. 77).

Os caracteres preconizados por Dworkin podem, a título de exemplificação, ser verificados no cotejo entre a função social da propriedade e a liberdade de iniciativa: ambas podem conflitar, mas subsistirão válidas. Além disso, também possuem uma dimensão de peso a ser aferida no caso concreto, a qual determinará a proporção de sua eficácia.

Forçoso anotar a circunstância de que Dworkin, ao propor sua crítica à noção positivista de que o direito apenas seria composto de regras, recorre ao termo princípio para referir-se a qualquer norma integrante de um ordenamento. Para ele, os princípios poderiam apresentar-se sob dois formatos: o de princípio stricto sensu ou o de diretriz. Esta representaria o "tipo de estándar que propone un objetivo que ha de ser alcanzado; generalmente, una mejora en algún rasgo económico, político o social de la comunidad", ao passo que aquele seria "un estándar que ha de ser observado, no porque favorezca o asegure una situación económica, política o social que considera deseable, sino porque es una exigencia de la justicia, la equidad o alguna otra dimensión de la moralidad" (DWORKIN, 1997, p. 72). Conclui-se que a função social da propriedade, na doutrina daquele pensador, apresenta-se como princípio (em sentido lato), mas consubstancia clara manifestação da espécie diretriz.

Outra propalada e pertinente distinção entre princípios e regras é a formulada por Alexy, para quem as regras seriam mandatos definitivos, enquanto os princípios seriam mandatos de otimização. Para aquele jurista alemão, os princípios seriam assim caracterizados porque "ordenan que al go sea realizado en la mayor medida posible, de acordo con las posibilidades jurídicas e fácticas". Não há nos princípios, pois, a orientação para que o valor neles inserto seja plenamente efetivado. Assim como Dworkin, Alexy aponta como precípuo critério distintivo entre as regras e os princípios reside na atividade de ponderação exigida quando da colisão destes (ALEXY, 1997, p. 86 e 89).

Como se vê, a distinção entre princípios e regras preconizada por Dworkin e Alexy é essencialmente a mesma, como reconhece Paulo Bonavides (2001, p. 248), e reforça a conclusão de que a função social da propriedade apresenta a natureza jurídica de princípio.

Acrescente-se que em nosso direito, assim como nas legislações da atualidade, o princípio da função social da propriedade ostenta cunho constitucional, detendo aplicabilidade imediata (art. 5o, §1 ${ }^{\circ}$, da Constituição Federal) (SILVA, 2002, p. 281-282). 


\section{REFLEXOS DO PRINCÍPIO DAFUNÇÃO SOCIAL PARAA REINVESTIGAÇÃO DA NATUREZAJURÍ DICA DA PROPRIEDADE}

Já se pôde perceber nas linhas antes desenvolvidas que a noção de propriedade sofreu inúmeras alterações no curso da história. Essa mutabilidade parece ser inerente à sua natureza, por conta da inegável relação existente entre o delineamento da propriedade e as doutrinas econômicas, sociológicas e políticas vivenciadas pelo homem através dos tempos.

Como exemplo disso, sabe-se que o extremo individualismo que informava o regulamento da propriedade já fora apto para conduzir à concepção de que o proprietário e a coisa mantinham entre si uma relação jurídica, a qual a mais ninguém interessaria (GONÇALVES, 1952, p. 53).

Divisada na propriedade atualmente uma função social, forçoso se mostra reinvestigar a sua natureza jurídica.

Antes dessa modificação efetiva do tratamento jurídico da propriedade, todas as considerações tecidas pela doutrina nesse tocante pareciam convergir para encarar a propriedade sob dois aspectos primazes:

- seria a propriedade direito subjetivo e

- seria a propriedade absoluta, no sentido de ser ampla a liberdade do proprietário ao extrair as benesses que lhe são deferidas pela coisa, encontrando apenas as limitações impostas pela lei.

Oportuno ressaltar que símile posicionamento também se faz assumido em estudos que, não obstante posteriores à efetiva inserção do princípio da função social no regramento da propriedade, parecem insistir em olvidá-la ou deferir-lhe menor atenção, o que, restando demonstrada tal alteração do regulamento jurídico da propriedade, pode ser justificado como ranço da ultrapassada secessão entre o Direito Civil e o Direito Constitucional e da insistência no caráter individualista da propriedade. Demonstração disso é a circunstância de os compêndios de Direito Civil normalmente referirem-se à função social como limitação da propriedade (v., entre outros, VENOSA, 2003, p. 157, 163 e 164). Esse aspecto é hábil para reforçar a relevância do estudo a ser doravante desenvolvido.

Insta, primeiramente, arrolar alguns conceitos de propriedade, a fim de verificar a correção do antes asseverado, indicando-se, em início, os formulados por Orlando Gomes. O autor apresenta três conceitos que afirma serem complementares entre si. Consoante o primeiro, de cunho sintético, seria a propriedade a "submissão de uma coisa, em todas as suas relações, a uma pessoa". Num conceito analítico, seria "o direito de usar, fruir e dispor de um bem, e de reavê-lo de quem injustamente o possua". Por fim, numa abordagem descritiva, seria a propriedade "o direito complexo, absoluto, perpétuo e exclusivo, pelo qual uma coisa fica submetida à vontade de uma pessoa, com as limitações da lei" (GOMES, 2004, p. 109). 
Símiles elementos podem ser identificados no conceito elaborado por Cunha Gonçalves. Para ele, a propriedade é o direito "que uma pessoa singular ou coletiva efetivamente exerce numa cousa certa e determinada, em regra, perpetuamente, de modo normalmente absoluto, sempre exclusivo e que todas as outras pessoas são obrigadas a respeitar". A amplitude dos poderes do proprietário é ressaltada mediante a atribuição de um caráter "normalmente absoluto" à propriedade, em virtude do qual "o proprietário pode gozar da sua coisa pelo modo que lhe aprouver, transformá-la, abandoná-la, destruí-la". Quanto ao caráter exclusivo da propriedade, aquele jurista afirma significar que "o proprietário pode opor-se a que outra pessoa tire da sua cousa qualquer proveito, sem seu consentimento, salvas as restrições do mesmo direito fixadas na lei" (GONÇALVES, 1952, p. 66).

Faz-se mister frisar que o caráter absoluto da propriedade, com o qual the qualificam os mencionados autores, não pode ser encarado no sentido de ausência de limitação aos poderes do proprietário. Ora, tal análise negaria o direito, mesmo que encarado sob uma acepção liberal. A prescrição de limites à conduta humana é essencial ao direito, não obstante a isso ele não se resuma. Direito e absolutismo - em sua acepção pura - são, pois, conceitos mutuamente excludentes.

O absolutismo da propriedade encerra, na verdade, sua oponibilidade erga omnes, ou seja, contra todos, característica comum a todos os direitos reais. Isso significa que o exercício regular da propriedade deve ser respeitado pela universalidade dos indivíduos, que não devem interferir no âmbito do proprietário, consoante disciplinar a norma jurídica. Quando surgida alguma conduta tendente àquela interferência, pode o proprietário opor seu direito em face da pretensão alheia, a qual, destarte, não receberá a guarida do ordenamento jurídico. Não há mais como vislumbrar a propriedade como relação entre sujeito e coisa ${ }^{13}$, o que importaria, no mínimo, o inestimável equívoco de personificar a coisa ou - o que é pior - coisificar o sujeito, em visível atentado à dignidade da pessoa humana. Em sede de propriedade, a relação jurídica dá-se entre o proprietário e todo o restante da coletividade, o qual se costuma denominar sujejto passivo universal ${ }^{14}$.

${ }^{13}$ Cunha Gonçalves afirmava que, nos direitos reais, "figura uma só pessoa ativa, isto é, a relação existe diretamente, entre uma pessoa e uma cousa certa, e indiretamente, com a generalidade de pessoas indeterminadas, que só têm o dever genérico e passivo de não-lesar, não-perturbar ou impedir o exercício de tais direitos" (1951, p. 64). Atualmente, não há como dar acatamento à afirmação do eminente jurista quanto à existência de uma relação entre pessoa e coisa, a qual apenas pode ser delineada em sentido figurado e alheio à ciência jurídica.

${ }^{14}$ Orlando Gomes alude a uma distinção entre o caráter absoluto dos direitos reais e sua oponibilidade erga omnes - aqui tratados indistintamente -, embora afirme que "o direito real, sendo um direito absoluto, opõe-se a todos, que teriam um dever negativo" (com grifos nossos). Para o mestre baiano, a oponibilidade representaria o "poder que tem o titular de tornar eficaz e exercer o direito 
Encarado o absolutismo da propriedade como plenitude de poderes, ocasionar-se-iam efeitos que inviabilizariam a convivência social, pois, como pontifica José de Oliveira Ascensão, a propriedade "é o direito real que outorga a universalidade dos poderes que à coisa se podem referir" (1993, p. 448). Com efeito, indubitável ser a propriedade o direito real mais amplo que há. Todos os demais direitos reais, ditos direitos reais sobre coisa alheia (jus in re aliena) ${ }^{15}$, seriam fruto de desmembramento dos poderes ínsitos à propriedade (jus in re propria). Destarte, é impensável que tal poder não encontre amarras e, de fato, a propriedade sempre encontrou limites de maior ou menor extensão.

Também assevera Pontes de Miranda que propriedade ${ }^{16}$ é "o mais amplo direito sobre a coisa" (1983, p. 9), mas reconhece aquele jurista que o proprietário sofre limitações, embora sejam elas alheias ao conteúdo do direito de propriedade, ou seja, a essência desse direito em nada exige tais limitações; elas não integram o direito em si, mas apenas the traçam os contornos. Essa ideia se coaduna com a noção de ser a propriedade um direito subjetivo, sobre cuja noção pondera o próprio Pontes de Miranda, ao afirmar que "todo direito subjetivo é linha que se lança em certa direção. Até onde pode ir, ou até onde não pode ir, previsto pela lei, o seu conteúdo ou seu exercício, dizem-no as regras limitativas, que são regras que configuram, que traçam a estrutura dos direitos e da sua exercitação" (MIRANDA, 1983, p. 18).

Nessa linha de pensamento, o autor enfatiza sua discordância em face das doutrinas que se inclinam à inserção de limitações na própria estrutura do direito de propriedade:

A tentativa de apontar os limites legais como algo que desce à própria finalidade da propriedade proveio da preocupação defensiva de teorias políticas de extrema direita, que, diante da transformação da economia e do direito, quiseram negar serem algo de extrínseco essas limitações de conteúdo. Com isso, pretendiam aproximar-se da antítese, que seria a publicização radical pregada pelo comunismo, apresentando-se como síntese (MIRANDA, 1983, p. 16).

Não há, contudo, como negar os reflexos que essas transformações econômicas e jurídicas representaram para o modo com que se encara a propriedade. Ora, ela hoje existe porque o direito lhe assegura existência e é esse mesmo direito que preceitua a

sobre a coisa em cotejo com qualquer pessoa que se encontre eventualmente em relação com a mesma coisa", enquanto o caráter absoluto redundaria na suscitação de uma "obrigação passiva universal", ou seja, num dever coletivo de não-ingerência (1981, p. 54).

${ }^{15}$ No atual direito brasileiro, tais direitos vêm arrolados, ao lado do de propriedade, no art. 1225 do Código Civil, a eles devendo ser aduzida a enfiteuse, por força do art. 2038 daquela Lei.

${ }^{16}$ Aqui o conceito é empregado no sentido estritíssimo, na terminologia adotada pelo jurista alagoano. Para ele, a propriedade seria, em sentido amplíssimo, sinônima a patrimônio. Em sentido amplo, o termo designaria qualquer direito real (MIRANDA, 1983, p. 9). 
sua estrutura, estabelecendo os contornos do âmbito de atuação do proprietário. Se o tratamento juridicamente deferido à propriedade nos tempos atuais é diverso do de outrora, forçoso perquirir se remanesce sua caracterização como direito subjetivo. Para tanto, deve-se analisar se a norma apenas limita a ação do proprietário ou se a este é remetida juridicamente alguma prestação de cunho positivo. Em sendo a propriedade direito subjetivo, seria possível afirmar que o proprietário encontrará apenas os limites que a norma jurídica traça ou também serão a ele confiadas prestações positivas? Cumpre identificar, pois, o que se deve entender por direito subjetivo, a fim de verificar a sua compatibilidade com a noção atual de propriedade.

Nos termos da lição de Goffredo Telles Júnior:

Os direitos subjetivos são permissões dadas por meio de normas jurídicas. [...] Quem tiver permissão jurídica para fazer ou não fazer alguma cousa, para ter ou não ter alguma cousa, possui o direito (o direito subjetivo) de fazê-la ou não fazê-la, de tê-la ou de não tê-la (TELLES JÚNIOR, 1977, p. 298).

Símile é noção de Miguel Reale, para quem "direito subjetivo é a possibilidade de exigir-se, de maneira garantida, aquilo que as normas de direito atribuem a alguém como próprio" (REALE, 2000, p. 262).

Oportuno indagar se se enquadraria nesses conceitos a propriedade, considerado o tratamento jurídico a ela dispensada na atualidade. Seriam conferidas ao proprietário apenas permissões ou também deveres? Atribuir-se-ia ao dono apenas a possibilidade de exigir algo ou poderia ele ser exigido para algo?

Caio Mário da Silva Pereira ressalta de modo lapidar e sintético a conformação hoje verificada para a propriedade, o que se apresenta de inestimável relevância para alcançar as respostas a tais questionamentos:

[...] Crescem os processos expropriatórios, sujeitando a coisa à utilidade pública e aproximando-a do interesse social. Condiciona-se o uso da propriedade predial a uma conciliação entre as faculdades do dono e o interesse do maior número; reduz-se a liberdade de utilização e disposição de certos bens; sujeita-se a comercialidade de algumas utilidades a severa regulamentação; proíbe-se o comércio de determinadas substâncias no interesse da saúde pública; obriga-se o dono a destruir alguns bens em certas condições [...]. A ordem jurídica abandonou a passividade que guardava ante os conflitos de interesses e passou a intervir [...] no propósito de promover o bem comum [...]. Garante a ordem pública a cada um a utilização de seus bens, nos misteres normais a que se destinam [...] mas, em qualquer circunstância, sobrepõe o social ao individual (2004, p. 85-87).

Como se vê, não mais há como serem abrangidos pelos estreitos lindes da noção clássica de direito subjetivo as notas atribuídas à propriedade na atualidade. O comportamento do proprietário deixou de ser apenas limitado pela norma jurídica, passando a ser também por ela prescrito. A norma atribui ao proprietário não apenas 
poderes, como fazia outrora, mas poderes edeveres, em decorrência da consagração da função social da propriedade. Esta ostenta, assim, duas facetas que se integram e complementam: uma, negativa, ante a qual os clamores do interesse social impõem ao proprietário limites a seu poder, e outra, positiva, que remete ao proprietário deveres cujo descumprimento enseja as sanções cominadas pela norma.

Daí porque não se pode considerar a função social da propriedade como mera limitação aos poderes do proprietário, pois, como afirma Orlando Gomes, "as limitações atingem o exercício do direito de propriedade, não a sua substância [...]. Sua finalidade social determina a modificação conceitual do próprio direito, que não se confunde com a política das limitações específicas ao seu uso" (2004, p. 128-129).

Resulta evidenciado que a propriedade não mais faz surgir apenas liberdades e limites para o proprietário e limitações para os não-proprietários. Atualmente, não se pode apenas afirmar que o proprietário pode ir até onde lhe seja permitido. A ele são também atribuídas pela norma prestações positivas ${ }^{17}$, para que exerça a propriedade de modo a extrapolar o perímetro traçado em torno dela pelo interesse individual e, assim, aproximar-se do interesse coletivo. Não é diversa a opinião de Eros Grau, que leciona:

\begin{abstract}
Analisados os conjuntos das disposições normativas em que se desenham os perfis dos direitos de propriedade, nos quais o legislador ordinário contempla, sob a inspiração da função social, limitações da propriedade, verificaremos que, algumas vezes, neles se inserem comandos voltados não apenas à limitação do exercício do direito - para que não venha a contrariar a utilidade social - mas também à promoção do exercício de tal direito de modo mais compatível àquela utilidade (GRAU, 1977, p. 20).

O princípio da função social da propriedade impõe ao proprietário [...] o dever de exercê-la em benefício de outrem, e não apenas de não a exercer em prejuízo de outrem [...]. A função social da propriedade atua como fonte de comportamentos positivos - prestação de fazer, portanto, e não meramente de não fazer - ao detentor do poder que deflui da propriedade (1990, p. 250).
\end{abstract}

Aquele autor também afirma ser incompleta a ideia de que a propriedade não deve ser empregada de modo a contrariar a sua utilidade social, aduzindo que, nas formas de propriedade que considera afetadas pelo princípio da função social, não há

\footnotetext{
${ }^{17}$ Não se pode, destarte, ratificar o pensamento de Vicente Rodrigues Alves, segundo quem "a função social da propriedade, conceito ligado à crescente relativização dos direitos, traduz-se numa não-contrariedade a interesses sociais relevantes pelo titular do direito de propriedade, ou por outrem, na efetivação de seus interesses particulares. [...] Não se trata de reconhecer, com a idéia de que o exercício do direito de propriedade tem uma função social, deveres, mas de limitar direitos, de modo que o interesse individual, em sociedade, fique com sua ação ou mesmo omissão limitada à justa liberdade da ação ou omissão alheia, diante do interesse coletivo nos seus justos limites" (ALVES, 1992, p. 185-186).
} 
apenas propriedade, mas propriedade função social. Para ele, o princípio da função social da propriedade impõe profundas alterações estruturais no conceito jurídico-positivo da propriedade (GRAU, 1990, p. 251).

Reafirma-se, com isso, ante as substanciais alterações impostas à propriedade pela ordem jurídica, não haver como insistir em considerá-la direito subjetivo, pelo menos se considerado nos moldes em que foi caracterizado supra. A propriedade, ante a função social que lhe impregna, não é por ela meramente limitada, mas também estruturada. O proprietário de hoje o é para atender aos seus interesses e aos interesses da sociedade, detendo um poder-dever, de sorte que propriedade e função social passam a ser conceitos indissociáveis. Daí porque alguns passaram a referir-se à propriedade como função social, como visto alhures. Nesses termos, vislumbrar-se-ia nas mãos do proprietário não um direito, mas uma função social a ser por ele desempenhada.

Desponta como expoente maior dessa tese o já comentado Léon Duguit, para quem "la proprietén'est plus le droit subjectif du propriétaire, elle est la fonction sociale du détenteur de la richesse" , "la conception de la propriété droit subjectif disparaît pour faire place à la conception de la propriété fonction sociale" (1923, p. 618-620).

Malézieux corrobora tal entendimento, ao afirmar:

Dans la conception classique, le droit de proprieté conferait essentiellement des prérogatives à son titulaire. D 'importantes tranformations conduisent peu à peu à une notion assez différente envertu de laquelle le proprieté a non seulemente des droits mais également des devoirs. $0 \mathrm{n}$ a pu dire que le proprieté, envisagée à I'origine commeune liberté individuelle, s'est peu à peu transforméeen fonction sociale (MALÉZIEUX, 1973, p. 24).

Entre nós, Antônio Jeová Santos apregoa que a teleologia do direito "foi se desenvolvendo no fluir da história até abrir o rumo tendente a compreender a propriedade como uma função que tem que ser cumprida, uma função social, e que, enquanto o proprietário a cumpra, seus atos estarão protegidos" (2004, p. 123).

A resposta ao problema, contudo, parece não consistir em enquadrar-se a propriedade no conceito de direito subjetivo ou no de função social, mas em verificar-se a adequação de tais conceitos à realidade atual.

Considerar atualmente o direito subjetivo como mera faculdade de agir (facultas agendi), conforme concebido pela pandectística, equivaleria a olvidar a evolução imposta pelas sucessivas doutrinas econômicas e políticas antes analisadas. Ser titular de um direito não mais significa ter à disposição um abrigo contra intervenções de outrem, como se verificava outrora. Os direitos não mais podem ser encarados apenas sob uma perspectiva individual, mas também coletiva. Na precisa anotação de Orlando Gomes, não mais se mostra viável assimilar as notas clássicas do direito subjetivo, 
posição omissiva, a autonomia privada começou a murchar e a noção de dever se impôs no plano dos comportamentos individuais antes que de direitos (1981, p. 57).

Por outro lado, a orientação do extremo oposto, em que se divisaria a afirmação de que a propriedade tornou-se função social, pode conduzir à errônea noção de que o proprietário deve aplicá-la em detrimento de seus interesses individuais. Como ensina Messineo, "función es una potestad que se ejercita, no por un interés propio ( 0 al menos no por un interés exclusivamente propio), sino por un interés ajeno, o por un interés objetivo" (MESSINEO, 1954, p. 254), i.e., por um interesse que se situa fora do indivíduo que exercita o mencionado poder. Nesse sentido, esclarece Fábio Konder Comparato que o termo função, em direito, representaria um poder-dever através do qual o agente perseguiria sempre o interesse alheio e não os seus interesses próprios, sendo qualificada de social se desempenhada em benefício da coletividade, e não no de pessoas determinadas (COMPARATO, 1996, p. 41).

A caracterização da propriedade como uma função resultaria, pois, na conclusão de que o proprietário agiria prioritariamente para a satisfação do interesse social, de sorte que os benefícios que a propriedade lhe proporcionaria seriam apenas indiretos. Não é essa, em verdade, a tese que encontra ressonância nos ordenamentos hodiernos, a exemplo do que se verifica no direito doméstico (art. $5^{\circ}$, XXII e XXIII, da Constituição Federal). Diga-se, ademais, que tal conclusão negaria o já exposto caráter dialético da propriedade ora vigorante, ao distanciá-la dos interesses individuais.

Percebe-se que é 0 conceito de direito subjetivo, em verdade, aquele que se apresenta merecedor de modificação, a fim de adequar-se também aos ditames do social, ao lado do individual, o que já vem sendo observado pela doutrina. Insere-se agora na noção de direito subjetivo a prescrição de condutas ativas por parte de seu titular, o que já se identificava no art. 153 da Constituição de Weimar, antes transcrito (v. item 1, supra), especificamente no que toca ao direito subjetivo do proprietário: a propriedade obriga.

Radbruch reconhece tal modificação conceitual no direito subjetivo, a qual vislumbra como uma "penetração que sofre a facultas agendi por uma idéia de dever ou função social com um determinado conteúdo", apontando exatamente a propriedade como exemplo dessa evolução (RADBRUCH, 1997, p. 257).

Nesse sentido, pontifica Orlando Gomes que

o direito não mais pode ser concebido na época atual como um mero sistema de limites às esferas jurídicas individuais ou como um sistema de imperativos estatuídos pelo Estado em defesa de tais esferas, já tendo passado a ser considerado um fator institucional na vida econômica e social (1981, p. 58).

Constata-se, ante o exposto, que a propriedade conforma-se atualmente como direito subjetivo de natureza real, no qual se insere a orientação de uma função social. 
Garantem-se ao proprietário as vantagens proporcionadas pela coisa sob sua senhoria, mas lhe são impostos limites e deveres para que tal coisa também se veja a serviço da sociedade. Nessas linhas se desenvolveu o art. 832 do Código Civil italiano de 1942, o qual, em plena ilustração aos novos contornos assumidos pelo direito de propriedade, preceitua que "il proprietario ha diritto di godere e disporre delle cose in modo pieno ed esclusivo, entro i limiti e con I'osservanza degli obblighi stabiliti dall'ordinamento gi uridico" ${ }^{18}$.

Era tal a tese que Cimbali, ainda nos albores do século XX, preconizava para a propriedade. Afirmou aquele civilista italiano:

La proprietà, oltrechè diritto e più che semplice diritto individuale, è altissima funzione sociale [...]. L'esercizio del diritto trova il suo titolo e le sue condizioni nell'adempimento dei doveri, che ad esso si collegano. Ciò, come avviene per altri diritti, con maggiore ragione deve aver luogo nel diritto di proprietà, che è quello chiamato a provvedere dei mezzi di sussistenza e di sviluppo la convivenza sociale (CIMBALI, 1907, p. 187-188).

Eros Grau, corroborando tal entendimento, não vislumbra nenhuma incompatibilidade entre a noção de direito subjetivo e a de função social da propriedade, inexistindo, segundo ele, qualquer contradição dogmática entre elas (1983, p. 70).

José Afonso da Silva reconhece as modificações impostas pela função social à natureza da propriedade, retirando-lhe o caráter privado para inseri-la no Direito Público. Cinge-se, contudo, a afirmar a inserção da função social no direito de propriedade, quando assevera que "o direito de propriedade (dos meios de produção especialmente) não pode mais ser tido como um direito individual. A inserção do princípio da função social, sem impedir a existência da instituição, modifica sua natureza" (2002, p. 280-283).

A maior parte da doutrina aponta no sentido de ser a propriedade um direito subjetivo integrado por uma função social ${ }^{19}$, conclusão à qual se afilia a análise ora delineada. É sob esse prisma, pois, que deve ser entendida a expressão "direito de propriedade" a que aludem os arts. 5, XXII, da Constituição Federal, e 1228, §1º do Código Civil de 2002.

${ }^{18}$ Analisando tal dispositivo, Messineo também defende o ora asseverado, embora prefira afirmar que "se atribuye a la propiedad una finalidad, pero no una función social", apenas para o preciso fim de esclarecer que não era o objetivo do legislador italiano de 1942 "concebir la propiedad como función", o que se resume a uma divergência meramente terminológica. Daí porque aduz que "una cosa es ejercer también una función social, y otra es que la propiedad sea exclusivamente una función y que el propietario, al actuar, no pueda perseguir ningún interés suyo propio" (MESSINEO, 1954, p. 254-255).

${ }^{19}$ Entre outros, GOMES, 1977, p. 171-172, e VAZ, 1993, p. 153. Esta afirma que todas as formas de propriedade são "submetidas ao preceito de função social, que não acarreta [...] a supressão do princípio constitucional garantidor do direito à propriedade privada", apenas modificando a natureza do direito subjetivo do proprietário (loc. cit.). 


\section{CONSIDERAÇÕES FINAIS}

Ante o exposto, pode-se concluir que:

a) o surgimento do Estado Intervencionista, o qual reuniu elementos oriundos do liberalismo e do socialismo, permitiu a concepção de uma propriedade dotada de função social, ante a qual o proprietário deveria conduzir-se de modo a compatibilizar os seus interesses individuais e os interesses coletivos;

b) tal função social da propriedade, da qual se originou uma atribuição de deveres de índole coletiva aos proprietários, consubstancia princípio que passou a ser reconhecido em diversos ordenamentos jurídicos; e

c) essa atribuição de deveres ao proprietário gerou, por consequência, a necessidade de readequação do conceito de direito subjetivo, o qual deixou a condição de mera faculdade de agir. A propriedade, destarte, passou a caracterizar-se como direito subjetivo integrado por uma função social.

\section{REFERÊNCIAS}

ALEXY, Robert. Teoría de los derechos fundamentales. Trad. Ernesto Garzón Valdés. Madrid: Centro de Estudios Constitucionales, 1997.

ALVES, Vilson Rodrigues. Uso nocivo da propriedade. São Paulo: Revista dos Tribunais, 1992.

ARAÚJO, Telga de. Função social da propriedade. In: FRANÇA, R. Limongi (Coord.). Enciclopédia Saraiva do Direito. Vol. 39. São Paulo: Saraiva, 1977.

ARISTÓTELES. Política. Trad. Torrieri Guimarães. São Paulo: Martin Claret, 2002.

ASCENSÃO, José de Oliveira. Direito Civil: reais. Coimbra: Coimbra, 1993.

BEVILÁQUA, Clóvis. Direito das Coisas. Rio de Janeiro: Rio, 1976.

BONAVIDES, Paulo. Curso de Direito Constitucional. 11. ed. São Paulo: Malheiros, 2001.

CIMBALI, Enrico. La nuova fase del diritto civile nei rapporti economici e sociali. In: Opere complete di Enrico Cimbali. Vol. I. 4. ed. Torino: Unione TipograficoEditrice Torinese, 1907.

COMPARATO, Fábio Konder. Estado, empresa e função social. Revista dos Tribunais. São Paulo, v. 732, p. 38-46, out. 1996.

COMTE, Auguste. Système de politique positive. Tomo I. 3. ed. Paris: Chez Carilian-Goeury et Vor Dalmont, 1851. 
DALLARI, Dalmo de Abreu. Elementos de teoria geral do Estado. 19. ed. São Paulo: Saraiva, 1995.

DUGUIT, Léon. Las transformaciones generales del derecho privado desde el Código de Napoleón. Madrid: Librería Española y extranjera, 1920.

. Traitéde Droit Constitutionnel. Tomo III. 2. ed. Paris: Ancienne Librairie Fontemoing \& Cie Éditeurs, 1923.

DWORKIN, Ronald. Los derechos en serio. Trad. Marta Guastavino. Barcelona: Ariel, 1997.

FALCÃO, Raimundo Bezerra. Tributação e mudança social. Rio de Janeiro: Forense, 1981.

GALBRAITH, John Kenneth. American Capitalism - TheConcept of Countervailing Power. Massachussets: Houghton Mifflin Company Boston, 1952.

GOMES, Orlando. Direitos Reais. 19. ed. Rio de Janeiro: Forense, 2004.

Escritos menores. São Paulo: Saraiva, 1981.

e VARELA, Antunes. Direito Econômico. São Paulo: Saraiva, 1977.

GONÇALVES, Luís da Cunha. Da propriedade e da posse. Lisboa: Ática, 1952.

Princípios de Direito Civil Luso-Brasileiro. Vol. I. São Paulo: Max Limonad, 1951.

GRAU, Eros Roberto. A ordem econômica na Constituição de 1988: interpretação e crítica. São Paulo: Revista dos Tribunais, 1990.

Direito Urbano, regiões metropolitanas, solo criado, zoneamento e controle ambiental. São Paulo: Revista dos Tribunais, 1983.

. Função social da propriedade (Direito econômico). In: FRANÇA, R. Limongi (Coord.). Enciclopédia Saraiva do Direito. Vol. 39. São Paulo: Saraiva, 1977.

O discurso neoliberal e a teoria da regulação. In: CAMARGO, Ricardo Antônio Lucas (Org.). Desenvolvimento econômico e intervenção do Estado na ordem constitucional. Porto Alegre: Sergio Antonio Fabris, 1995.

KLEIN, Lawrence R. La revolución keynesiana. Trad. Francisco Javier Osset. Madrid: Editorial Revista de Derecho Privado, 1952.

MALÉZIEUX, Raymond. Droit rural. Paris: Presses Universitaires de France, 1973.

MALUF, Sahid. Teoria Geral do Estado. 25. ed. Atualizada por Miguel Alfredo Malufe Neto. São Paulo: Saraiva, 1999. 
MARX, Karl. Manuscritos econômico-filosóficos. Trad. Alex Martins. São Paulo: Martin Claret, 2001.

e ENGELS, Friedrich. Manifesto do Partido Comunista. 7. ed. São Paulo: Global, 1988.

MESSINEO, Francesco. Manual de derecho civil y comercial. Tomo III. Trad. Santiago Sentís Melendo. Buenos Aires: Ediciones Jurídicas Europa-America, 1954.

MIRANDA, Alcir Gursen de. Teoria de direito agrário. Belém: CEJUP, 1989.

MIRANDA, Pontes de. Tratado de Direito Privado. Vol. XI. 4. ed. São Paulo: Revista dos Tribunais, 1983.

MONCADA, L. Cabral de. Estudos de direito público. Coimbra: Coimbra, 2001. PEREIRA, Caio Mário da Silva. Instituições de direito civil. Vol. IV. 18. ed. Rio de Janeiro: Forense, 2004.

RADBRUCH, Gustav. Filosofia do Direito. Trad. L. Cabral de Moncada. Coimbra: Armênio Amado, 1997.

REALE, Miguel. Lições preliminares dedireito. 25. ed. São Paulo: Saraiva, 2000.

REICH, Norbert. Intervenção do Estado na economia (reflexões sobre a pósmodernidade na teoria jurídica). Trad. Fernando Herren Aguillar. Revista de Direito Público. São Paulo, v. 94, p. 265-282, abr-jun. 1990.

ROCHA, José de Albuquerque. Estudos sobre o Poder Judiciário. São Paulo: Malheiros, 1995.

SANTOS, Antônio Jeová. Função social do contrato. São Paulo: Método, 2004.

SANTOS, Eduardo Sens dos. A função social do contrato. Florianópolis: OAB/ SC, 2004.

SILVA, José Afonso da. Curso de Direito Constitucional Positivo. 20. ed. São Paulo: Malheiros, 2002.

TELLES JÚNIOR, Goffredo. Direito subjetivo - I. In: FRANÇA, R. Limongi (Coord.). Enciclopédia Saraiva do Direito. Vol. 28. São Paulo: Saraiva, 1977.

VASCONCELOS, Arnaldo. Teoriadanormajurídica. 4. ed. São Paulo: Malheiros, 1996. VAZ, Isabel. Direito econômico das propriedades. 2. ed. Rio de Janeiro: Forense, 1993. VENOSA, Sílvio de Salvo. Direito civil: direitos reais. 3. ed. São Paulo: Atlas, 2003. 


\section{REEXAMINING PROPERTY LAW}

Abstract: The conception of the Interventionist State, generated by a historical dialetical process verified between the Liberal State and the Socialist one, allowed the consecration of a social function to be observed by the bearers of the ownership. After that, proprietors began to be demanded for a behavior directed to the satisfaction of its individual interests, since that made compatible to the collective interest. Such circumstance generated a rupture in the way with which property was fit in the Law system. It was not anymore a mere facultas agendi granted to the proprietors, but also a source of duties. For some, property would have been become into a social function. However, the fact was a change occurred at the notion of subjective right generated by the interventionism of the State, when property began to be understood as a right guided by a social function.

Keywords: Social function of the property. Liberalism. Socialism. Subjective right. 